OLEH MASIUK,

Zaporizhzhya National University (Zaporizhzhya, Ukraine)

e-mail: olegpm16@gmail.com, ORCID0000-0003-3853-5863

\title{
THE INFLUENCE OF COSMISM ON THE DEVELOPMENT OF SOCIAL HOPE
}

This paper reveals philosophical aspects of the cosmism's influence on social hope formation. The relevance of the topic of this work is the need to study the impact of space and its interpretations on the future of the geosocial organism of our planet, due to the increase of cataclysms and catastrophes that threaten the further existence of humanity. We used a dialectical approach, a method of intellectual inversion and a comprehensive analysis for the research and reproduction of social hope at the level of micro and macrocosms. It made possible to formulate a holistic vision of the design of the future and its influence on the further development of humanity. It concluded that the social universe center changes in the imagination of creator of a desired future. New projections of the future can create new social spaces that significantly change the microcosm of man and his interaction with the world around him. It proved that study, the usage and practice of the future designing is a progressive phenomenon for the future of human existence. Social hope should be in the interaction of micro and macrocosms in the social space. This harmonizes the view of the common future. The following obstacles to the development of hope such as the fate, fear and hope of man, which arise during rethinking the impact of cosmos on social processes, are described in the article. These obstacles are the means of determination the vectors of social perspectives. Guaranteeing the future result is a stimulation of social activity of improving the future social space. The author emphasizes that hope can affect preservation of the noosphere and extension of human existence. This process includes the creation of a future design ritual, which involves the rejuvenation of the noosphere, based on hope for each participant in the social space.

Keywords: humanity; noosphere; social spaces; social hope; social universe; cosmism; elpidaurgius; fate; fear; social expectations.

Introduction

Social hope is a unique reflection of a person's ideas about the functioning of outer space and its use in the personal life in society. A special place in the study of this subject is the definition of the center of social life universe based on existing cosmological and social theories. The "Man-Universe" connection is vital for designing the desired future as the foundation for ideas formation concerning social space and its perspective.

Cosmos of social hope consists of the center and planets in orbits that set the parameters for a future life. At different times God, Man, Progress, Society and Consuming were in the center of a space system. The system of social hope is not a direct reflection of the solar system, because hope is a change in the center of the future life, as well as the trajectories of other planets. Social microcosm of the future is instable due to polycentricism of social space. As a result, we can say that the study of the cosmism influence on the social hope creation is an actual topic for this scientific work.

Nikolai Berdyaev, Nikolai Rerich discovered religion base for research on the future existence of man in cosmism. Konstantin Tsiolkovsky, Alexander Chizhevsky, Vladimir Vernadsky, Pier Teilhard de Chardin focused on physical and biological in the development of future existence. Galina Zheleznyak (2012), Marina Rusyaeva (2013), Kornelia Boczkowska (2016), Roman Dodonov and Vira Dodonova (2019), Ellen Pearlman (2019) analyzed influence of social transformation on understanding of cosmic space.

The aim of our study is to analyze the influence of cosmism on the social hope development. The catastro- phic pessimism of the beginning of the new millennium revives interest to the study of the influence of cosmos on changes in public space. These studies will create a new understanding of the harmonious existence of person in the world.

\section{Methods}

The complexity of the interaction of projections of the future influenced the use of the dialectical approach to organize the study of social hope as a component of social space. To create social hope, we use the method of intellectual inversion. This method transfers the images of macrocosm to the projection of microcosm. For Galina Zheleznyak: "...there is a nonzero probability that other systems with biological life exist in the universe, except Solar and Earth" (Zheleznyak, 2012: 345). As a result, there is a nonzero probability that many other projections of the future microcosm for the creation of social hope exist in society, which we must accept and use.

In the cosmists' opinion, harmony must be a perspective of life, as it was seen by the followers of social stratification theory, when makes projection of the future. Vladimir Vernadsky described the way of a future balance: "In intensive and difficult modern life a man practically forgets that he and humanity are inextricably linked with the biosphere" (Vernadsky, 2004: 472). People must recognize the existence of other people's social life, the integrity of the world around us, and include this understanding in our projection of the future. Therefore, we guided a comprehensive analysis of social hope as a means of waiting for an improvement in the relationship between the microcosm and the macrocosm of social future life. 


\section{Results and Discussion}

Understanding of the future existence changes in the process of its conception development, but always returns to theocentrism in micro and macrocosm. Man is the main traveler on this way. Konstantin Tsiolkovsky put man in the universe's center. He thought that a man is a substitute for God. Konstantin Tsiolkovsky cites the following reasoning: "Superman gets better health, longevity, perfect mind, technical power, etc., that do not foresee early. He is God from this point of view" (Tsiolkovsky, 2004: 436). We transfer this anthropic principle to the perspective of social space. Social hope makes man a creator of his future universe, but this situation stimulates conflict between the creators of the best future. The increase in conflicting participants in the projection of the future forces them to return to the theocentric principle of interaction. The image of God removes the conflict in the projection of the future.

Anthropocentrism and theocentrism complement each other and create a rationale for social hope as a projection of an acceptable future. Pier Teilhard de Chardin described it like that: "Every soul in the world belongs to God in Christ, but, on the other hand, any reality around us belongs to our soul. As a result, all the perceptive reality through our soul belongs to God in Christ" (Teilhard de Chardin, 2004: 25). God exists in every man, which makes a chance to create personal universe on the principle of mercy and humanity. Organization of Interaction of microcosm and macrocosm socializes human activity in the perspective space of existence.

The social hope creation for the future existence is associated with an exceptional influence of a person. Marina Rusyaeva focuses on the creativity: "Society forms the idea of a peace for the man, development of his soul, perception of man as a cosmourge, artist of the world, creator of the universe" (Rusyaeva, 2013: 144). Cosmourge creates the universe based on the future's dominant projection. It is the base of social hope for only one designer of the future. Cosmourge is the author of personal universe, but he is not its center. Creator exists over his creation, in which microcosm determines macrocosm. The center is changing relative to the future perspective.

The hope for cosmos restructuring transferred to the socio-cultural space. Researchers at the beginning of the twentieth century create an understanding of the social future of the cosmic scale. Ellen Pearlman describes this situation: "Cosmism seeped into many aspects of creative life. In 1908, Alexander Bogdanov wrote Red Star, a science-fiction novel-utopia narrated about Mars, and in 1913, he penned Tektology, a Universal Organizational Science, acknowledged as a precursor to cybernetics and systems theory. That same year, the artist Kazimir Malevich designed the sets and costumes for the revolutionary Futurist opera Victory Over the Sun, with music by Mikhail Matyushin and texts by Aleksei Kruchenyk, who was the force behind ZAUM, or poetics beyond the min" (Pearlman, 2019: 86). Cosmourg in Russian cosmism creates its vision of a social device based on an understanding of the structure of cosmos. However, there are also opposite points of view that influenced the development of the future space of human life.

The America's cosmism plays an important role in the development of future design of existence. Kornelia Boczkowska focuses on harmony between person and cosmos in research of McCurdy, Launius, Oliver, Tribbe: "Since the beginning of the history of American space program, human spaceflight has been often portrayed as a spiritual quest whose ultimate goal is to lead humanity to achieved absolution, purification and finally eternity" (Boczkowska, 2016: 113). American society has embarked on a future development based on the hope of achieving the ideal of a person in harmony with cosmos. Emphasis should be placed on understanding the significance of the world in a man and the harmony of a man with the world.

We should make difference between the influence on the human life's value and human egoism, which fills the content of social hope. This "gravity" in the human universe influences the development of social hope. Internal and external vectors set the "orbit" for the future's designer and his understanding of other participants' "orbits" in the perspective of social relations. Thus, the center of the future existence projection determines potential for the events development and behavior of the subjects of a given space.

Pier Teilhard de Chardin described hope effects on the duration of social existence: "In order to stimulate one's action we need to anticipate a guaranteed result. We hope for an immortal winner" (Teilhard de Chardin, 2004: 330). As a result, a man with social hope has faith in immortality and acceptance of infinity. Social hope stimulates creation of a person's universe and approves its existence, which is reflected by one's creative activity.

Designer of social hope extrapolates the vision of life over acceptable time horizon that affects its duration in biological and social space. Such an attempt of continuation one's life in his children, apprentices and deeds is an attempt to gain social immortality. Consequently, in addition, there is the hope in the long-term existence of life's space.

The movement of cosmic bodies influences on the development of future events in public life, which is meaningful not only for astronomers, but also for cosmists. Alexander Chizhevsky analyzed the number of sunspots and the beginning of hostilities "All these sharp jumps in the activity of the Sun coincide with the greatest activity of all armies on all the fronts" (Chizhevsky, 2015: 246). Cosmic activity affects the modern life as well as the entire future. We can extrapolate the movement of cosmic bodies on perspective social relations as an image of the events development in the future.

In addition, Alexander Chizhevsky analyzes the Sun's influence on the vegetable world. Quantitative analysis shows: "The maximum activity of the Sun produces some specific radiation in space that has a special effect on the plants' growth" (Ibid: 252). Consequently, activity of the Sun stimulates survival at any cost. We think that this radiation can be either aid or stress. The center of the future's projection has a similar influence on the social hope participants.

The development of social hope has the character of an epidemic. We need to understand how the designing tendency influences informational space. Alexander Chizhevsky analyzed the impact of pseudo-discovery on scientists: "History of rays Blondeau is the fact of social suggestibility, which has not spared even the scholars whose activity has taught them to be critical to every fact" (Chizhevsky, 2015: 361). The pseudo- discovery united scholars as the center of scientific universe, which probably will change future life. Therefore, any "viral" idea can be the center of social hope in the relationship of micro and macrocosm.

The growth of social hopelessness also depends on the Sun, which affects the social world development. Many people do not feel the vitality in overcast weather. People feel it as hopelessness. A similar situation: hopeful man disappears from prospective social relationship. If visionary of social hope plays the role of the Sun, hope's performer plays the role of the earth.

\section{Space Movement of Social Hope}

Epidemic social relationships influence on social 
hope, nevertheless they are embedded in a subjective act of creation (theurgy). Nikolai Berdyaev described the process of creation's projection: "Theurgy is the continuation of the work of God's creation, God's creation is not finished, and the new cosmos is ever-renewing. Theurgic creative process in human life is the way to a new cosmos" (Berdyaev, 2015: 230). Theurgy affects the development of sacred hopes, which reveals the answers to questions about the quality and duration of human existence.

The act of creativity is an awareness of the connection of man with the cosmos. The act of designing the future is the application of theurgy to the life's perspective of development that people demand. Marina Rusyaeva perceives this as "The idea of creation which is a cosmic, and the planet power is the realization of active human nature, which is directed to change and transform the universe" (Rusyaeva, 2013: 143-144). In this case, social hope is the final image of an ideal universe for a man, reflecting this image in social space.

Social hope is the cause of change in social space that reflects the influences of microcosm on macrocosm. Hope stimulates action and is its goal. Such dualism confirms the sacral nature of social hope. In the modern atheist world, the main reason for hope is the survival of the author and his inner circle. Utilitarianism becomes the driving force for the development of the future, but as before, two factors are important: the subject and the place of being.

Man is the author and distributor of social hope. His roles are revised in the context of the new scientific and technological revolution and its influence on the social microcosm. Sergey Sonko speaks about the new level of life for people: "Ecotope" Homo Sapiens goes far beyond the organism level of the species' organization and covers the ecosystem level, forming an agroecosystem, as an ecological niche with moving spatial boundaries" (Sonko, 2019: 51). We will supplement this point of view with the fact that man's place in the creation of the future's projection determines his real role in the existing world ecosystem. $\mathrm{He}$ can be the author or reader of his future life in society.

It is important to remember for understanding the social hope that social space is not static as well as the expanding universe. However, in the social world there is a mirror image of the Hubble constant. A great volume of social hopes and their great distance from each other implies social universe's youth. This is because of existence the single big explosion in the universe. New hopes are constant explosions that give rise to other potential social spaces. They renew the entire social universe, which is changed under the influence of these explosions.

We can agree with the point of view, which considers love as the result of the hope movement. Pierre Teilhard de Chardin considered this process as a religious movement: "Christianity is the only stream of thought, bold and progressive enough to embrace practically and effectively the whole world with a creation of capable infinite perfection, where the faith and hope turn into love" (Teilhard de Chardin, 2004: 325). Love is perceived as a creation based on hope. Love is the root, cause of existence, which advocates the need for its continuation in the future. This phenomenon is a reflection of cosmic harmony at the microcosm level. It is a base of social hope.

Important elements for the projection of future include interaction between subject and place of being. If more subjects influence the improvement quality of social hope, then more creators of projections of future will worsen the future life. Creators as visionaries impose the idea of a future existence and invade in the future microcosm of the subject of social relations. Consequently, the space of the projection of the future tends to inter subjectivity, but depends on the objectification of social life. The more objective the social hope, the more comfortable the future existence.

\section{Barriers to social hope}

Perspective location of the "correct stars' location" depends greatly on the subject's state and the place of being. Basic barriers of social hope are expectations of society, which play the role of gravity in social space. Expectations are "cooled" hopes that fix the generally accepted picture of the future.

The primary cause of the social obstacles of hope is fate which is the action of supernatural forces. Soren Kierkegaard saw cure for fear as follows: "Fate can signify an opposing entity, which is the unity of necessity and chance" (Kierkegaard, 2014: 120). We do not share this point of view. Fate is an icon of fear and indifference of a man to the processes in the micro and macrocosm. Fate is an obstacle of macrocosm's level on the way of hope realization, but people can and should resist it. It is much more difficult for a person to cope with social expectations directed at him in public space. Fear is a faceless enemy of a person who is mostly subjective. It can be eliminated by working on yourself.

Fear is the driving force for the obstacles of a social and cosmogonic level. Fear is a protective mechanism that facilitates as well as interferes with human development. The paradox of fear can be suppressed by social hope. It enables active usage of hope in the implementation of promising social activities. This accurately reflected in the words "shaker of the universe" Chinggis Khan: "Afraid - do not do it, if you do - do not be afraid, if you did - do not regret". Consequently, hope is one of the means by which a person can and should shake his social universe to achieve the desired result.

Let us return to the sun's effect on the formation of social hope. Alexander Chizhevsky considered the sun radiation an obstacle to life development "This penetrating radiation inhibits the physiological functions of the body as was shown in my experiments of 1928-1929" (Chizhevsky, 2015: 27). The guiding element in the development of the future not only stimulates, but also holds back possible changes in the existence of interaction object. The Sun affects not only physiological functions, but also social activity, which requires a rethinking of the impact of global warming on social life.

The biggest social hope's barrier is the atheism of the social space subjects, which creates the void of their existence. A person is afraid of getting something. Instead of gaining the new opportunities and spaces for life, he feels a meaningless emptiness of the future. Nikolai Berdyaev describes the atheists' time as a halt in development: "The void that remains after liberation from natural and social objectivism must be filled by something after the "critical" denial of everything; it cannot be filled either by faith in the categorical imperative or by belief in the inviolability of mathematics" (Berdyaev, 2015: 131). Artificially created objects of social space cannot replace the absence of a controlling subject in the vision of the future. The space of social hope needs gravitational fields for the development of future existence.

Social hope barriers depend on the will of the author of this future projection, which affects his future. Once man doubted God's purpose, but now he constantly doubts his own purpose of existence. The choice punishment is the reaction of macrocosm to the man's reckless actions. Social hope is an expression of subjectivity and a starting point for overcoming obstacles of one's desired future. A person is stronger than fate and other obstacles when he can see God's purpose through his actions for prospective 
existence. The paradox of social space is that the greater the volitional subjectivity of the bearer of social hope, the smaller is the distance to the final goal.

Movement is the way to overcome obstacles for social hope. The basis of this movement is to overcome the social space in the desired direction. Nicholas Rerich determined the specifics of this movement: "It is so valuable to hear. It is so valuable to realize that the evolution of humanity in its unpredictable ways makes its way into the future" (Rerich, 2016: 89). Therefore, knowledge of the macro and microcosm is important for the advancement of social hope, which improves the overcoming of vital obstacles in an evolutionary way.

\section{Social Hope and Noosphere}

Vladimir Vernadsky deduces the existence of the noosphere based on evolutionary processes that speaks about the importance of meaningful and purposeful existence. For him: "Humanity is becoming a powerful geological force. We are faced with the question of rebuilding the biosphere in behalf of free-thinking humanity as a whole, taking into account our thoughts and deeds" (Vernadsky, 2004: 480). In this case, if we consider evolution to achieve a better future, then the noosphere consists of a set of real social hopes.

The noosphere is a universe of social hope, created by man from the images of a desired future life. Vladimir Vernadsky identifies a person as an architect of urgent changes on Earth: "For the first time, people are becoming the largest geological force. They have to work in order of renewing the area of their life, restoring it radically, comparing to the previous state" (Vernadsky, 2004: 480). Man subjugates theurology in the noosphere as a result of his own activity. The human universe is created by the thought of the future and which it should be. We clarify that this human role is dominant only in the noosphere.

We must understand the role of social hope in the development of the new viable social groups on the planet Earth. Pierre Teilhard de Chardin foresaw the role of hope in the deployment of the noosphere, which he called as the rethinking of the human existence idea: "The idea of becoming a multitude is to conquer all habitable space on the top of any other form of life. In other words, the spirit weaves and deploys the cover of the noosphere" (Teilhard de Chardin, 2004: 320). At the same time, social hope as a significant process involves not only the expansion of the desired existence, but also its preservation, which has become relevant since the onset of technological disasters on planet Earth.

Social hope contains the power of thought concerning the future, which is the belief of a person in the possibility of improving future life. Pierre Teilhard de Chardin assigns this role to Christianity: "Only this can unite the man and Universe in the act of life on modern Earth. Only it can inspire us and serve this great movement that draws us" (Teilhard de Chardin, 2004: 326). This synthesis of sensual and rational attitude to the future world is characteristic not only for Christians, but also for believers of other religions. The noosphere consists of hopes united by faith in the future and structured by a meaningful attitude of a person towards his life.

If the noosphere is perceived as a continuation of the Earth's structure, then it must function according to the laws of nature. However, social hopes are unbalanced, but rather directed towards the existence of a microcosm. Human's activity subordinated exclusively to its own benefit, which makes the noosphere dangerous for our planet's existence. The way out of this situation is to bring hope back to the external vector of development.

Based on the Greek construction of meanings, we can make elpidaurgius in which hope represented a creative ritual and elements of social practice. Creating social hope as a ritual involves social interaction based on the exchange of ideas about the future life. The vitality of social hope involves a large number of contacts with take part in public relations and loyalty to this projective mechanism.

\section{Conclusions}

The influence of cosmism on social hope is a combination of religious, cosmogonic and philosophical ideas about the desired future of society and the possibility of achieving it. If we use the cosmists' points of view, then we can build a universe of social hope, in which superman will be the center as a reflection of God in the social universe. Man's sensual attitude towards the desired direction of the future is an attraction of social hope. The desire for the future changes the motion vector of "the planets" around the visionary.

Because of its youthfulness, the social universe filled with a variety of social hopes and has a great space for their realization. New hopes are potential new social spaces that factually reflect the desired future existence. The dead social universe is the unknown future, which is identical with non-being.

The main social hope's obstacle is fate, which reflects in the planets, stars, and equivalent participants in social relations. Fate in the social space is the expectations of society from a person, which influence his future life vision. A person is stronger than fate if he has hope, which contains the desired guideline and incentive for change.

The modern noosphere consists of hopes, which extrapolates to the space of human existence. Today noosphere is not only the development, but also protection of the human future from catastrophes and cataclysms. The world of projections of existence has an indeterministic basis, because these constructions involve the synthesis of a sensual and rational relationship to life.

Human hopes in most cases are selfish images of the future, which are dangerous for the human environment. The way out of this state is the creation of elpidaurgius, which will replace theurgy and cosmology. This process implies the existence of a ritual for creating the future, which fully legalized promising social practice. Hope should become social and belong to everybody, not just a few people, who have determined the vector of society's development in the past. The meaningful future in the noosphere focuses on harmonious coexistence in an accessible perspective.

The prospect of the further research is to understand the creation of the harmonious man's existence in the social universe. A creative look at the individual and collective future will give hope that a person can present in it. Consequently, the prospect of social hope's study lies in the search for means of improving the noosphere so that it does not destroy the planet Earth.

\section{REFERENCES}

Berdyaev, N. (2015). Philosophy of freedom. The meaning of creativity. The experience of human justification. Moscow: Academic Project, 608 p. (in Russian)

Boczkowska, K. (2016). The impact of American and Russian Cosmism on the representation of space exploration in 20th century American and Soviet space art. Wydanie I, Poznań: Wydawnictwo Naukowe UAM, 438 p.

Chizhevsky, A. (2015). The solar pulse of life. Moscow: Iris Press, 363 p. (in Russian).

Dodonov, R. O. and Dodonova, V. I. (2019). Odukhotvorenyy kosmos vs bezdushnyy prostir. Scientific journal of Dragomanov National Pedagogical University. Series 7. Religious Studies. Cultural Studies. Philosophy. Issue. 40 (53): 85-93. (In Ukrainian) 
Kierkegaard, S. (2014). The concept of fear. Moscow: Academic Project, 224 p. (in Russian).

Nazarov, A. (2004). Cosmism and noosphere reality. Culture and time. № 2. pp. 10-14. (in Russian).

Pearlman, E. (2019). The Resurgence of Russian Cosmism. PAJ: A Journal of Performance and Art. Volume 41, Issue 2, pp. 85-92. DOI: https://doi.org/10.1162/paij_a 00475

Rerich, N. (2016). Fenugreek. The heart of Asia. St. Petersburg: $A B C, 228$ p. (in Russian).

Rusyaeva, M. (2013). Music cosmicism as a cultural phenomenon. Granny: Theoretical, theoretical and political almanac. No. 7. pp. 142-146 (in Russian)

Sonko, S. (2019). Man in Noosphere: Evolution and Further Development. Philosophy and Cosmology, Volume 22, pp. 51-74 Retrieved from http://ispcjournal.org/journals/2019-22/PhC_22Sonko.pdf (Accessed 01 July 2019.); DOI: https://doi.org/10.29202/phil-cosm/22/5.

Teilhard de Chardin, P. (2004). The future of man. New York: Doubleday, $556 \mathrm{p}$.

Tsiolkovsky, C. (2004). Cosmic philosophy. Collection. Moscow: IDLI, 493 p. (in Russian).

Vernadsky, V. (2004). Biosphere and noosphere. Moscow: Iris Press, 580 p. (in Russian).

Zheleznyak, G. (2012). Cosmicity in the paradigms of science of the new millennium. Gilea: Scientific Herald. Collection of scientific works. Kyiv: VIR UAN, Issue 59 (№4). pp. 343-349 (in Ukrainian).

\section{LIST OF REFERENCE LINKS}

Бердяев Н. Философия свободы. Смысл творчества. Опыт оправдания человека. Москва: Академический проект, 2015. 638 c.

Вернадский В. Биосфера и ноосфера. Москва: АйрисПресс, 2004. 580 c.
Додонов Р. О., Додонова В. І. Одухотворений космос vs бездушний простір. Науковий часопис Національного педагогічного університету імені М. П. Драгоманова. Серія 7. Релігієзнавство. Культурологія. Філософія / ред. рада: В.П. Андрущенко (голова); за ред. Н.Г. Мозгової. Київ: Вид-во НПУ імені М. П. Драгоманова, 2019. Вип. 40 (53). С. 85-93.

Железняк Г. Космізм у парадигмах науки нового тисячоліття. Гілея: Науковий журнал. Вип. 59 (№4). С. 343-349.

Кьеркегор С. Понятие страха. Москва: Академический проект, 2014. 224 с.

Назаров А. Космизм и ноосферная реальность. Культура и время. 2004. № 2. С. 10-14.

Рерих Н. Пажитник. Сердце Азии. Санкт-Петербург: АВС, 2016. 228

Русяева М. В. Музыкальный космизм как феномен культуры. Грані: Науково-теоретичний і громадсько-політичний альманах. 2013. № 7. С. 142-146.

Циолковский К. Космическая философия. Москва: Исследовательский центр духовно-мистической литературы, 2004. 493 с.

Чижевский А. Л. Солнечный пульс жизни / Сост. А. Л. Голованов. М.: АЙРИС-пресс, 2015. 352 с.

Boczkowska K. The impact of American and Russian Cosmism on the representation of space exploration in 20th century American and Soviet space art. Poznań: Wydawnictwo Naukowe UAM, 2016. 438 p.

Chardin Teilhard de P. The future of man. New York: Doubleday, 2004. 556 p.

Pearlman E. The Resurgence of Russian Cosmism. PAJ: A Journal of Performance and Art. 2019. Volume 41, Issue 2, pp. 85-92. DOI: https://doi.org/10.1162/paij a 00475.

Sonko S. Man in Noosphere: Evolution and Further Development. Філософрія і космологія. 2019. Т. 22, с. 51-74. DOI: https:/ /doi.org/10.29202/phil-cosm/22/5.

\section{Олег Масюк,}

Запорізький національний університет (м. Запоріжжя, Украӥна)

e-mail: olegpm16@gmail.com,ORCID0000-0003-3853-5863

\section{ВПЛИВ КОСМІЗМУ НА РОЗВИТОК СОЦІАЛЬНОї НАДІї}

Ця стаття розкриває фрілософські аспекти впливу космізму на формування соціальної надії. Актуальність теми вказаної роботи полягає у необхідності дослідження впливу космосу та його тлумачень на майбутнє геосоціального організму нашої планети, що обумовлено збільшенням катаклізмів та катастроф, які загрожують подальшому існуванню людства. Для дослідження та відтворення соціальної надії на рівні мікро- та макрокосму використано діалектичний та комплексний підходи, а також метод інтелектуальної інверсії, що дозволило сформулювати цілісне бачення проектування майбутнього та його впливу на подальший розвиток людства. Автор дійшов висновку, що центр соціального Всесвіту має властивість змінюватись під впливом творців соціальних сподівань. Нові проекції майбутнього можуть утворювати нові соціальні простори, які суттєво змінюють мікрокосмос людини та їі взаємодію з оточуючим світом. Доведено, що вивчення та використання проектування прийдешнього є прогресивним явищем для організації людського існування. Соціальна надія є засобом гармонізації взаємодії мікро- та макрокосму під час формування майбутнього соціального простору. У статті виокремлені такі перешкоди для розвитку надії, як доля, страх та очікування людини, які виникають при переосмисленні впливу космосу на соціальні процеси. Ці перешкоди є засобами для трансформації векторів соціальної перспективи в залежності від сприйняття оточуючого світу. Гарантування майбутнього результату є стимулюванням соціальної активності щодо вдосконалення майбутнього соціального простору. Автор підкреслює, що від формулювання конструктивних соціальних очікувань залежить збереження ноосфери та покращення людського існування. Цей процес включає створення ритуалу майбутнього дизайну соціального простору (ельпідаургія), який передбачає омолодження ноосфери, засноване на сподіваннях кожного учасника суспільних відносин.

Ключові слова: людство; ноосфера; соціальний простір; соціальне сподівання; соціальний всесвіт; космізм; ельпідаургія; доля; страх; соціальні очікування.

(C) Oleh Masiuk

Надійшла до редакції: 17.11.2019

Прийнята до друку: 17.01.2020

ISSN 1728-9343 (Print)

ISSN 2411-3093 (Online)

SKHID No. 1 (165) January-February 2020 